\title{
Bonuses to Board Members of State-owned Companies
}

\author{
Agata Sierpińska-Sawicz*
}

\begin{abstract}
Purpose - The paper presents the results of research into the bonus systems for board members of State-owned companies.

Design/methodology/approach - The research was carried out in two large capital groups covering a total of 25 companies, including two large parent companies in the raw materials sector and their 23 subsidiaries. The Author analysed Supervisory Board's resolutions regarding the assessment of the degree of objectives achievement and its relation to the bonus system.

Findings - The study shows that the objectives to assess achievement are not fully suited either to the type of activity pursued by the companies or the current market situation. Management bonus systems measure chiefly short-term objectives, and the weights used for individual metrics do not reflect the competences of individual board members.

Originality/value - Due to the short period of legal solutions validity and data confidentiality, there is no research in the literature regarding bonuses for management board members of State Treasury companies. The results of the research will improve the bonus systems for board members and increase management effectiveness in achieving a companies goals included in their strategies.
\end{abstract}

Keywords: management objectives, objective achievement metrics, bonuses

\section{Introduction}

The remuneration of Board members in State-owned companies consists of a fixed part whose monetary value depends on the size of the company, a variable part depending on the degree of achievement of management objectives and supplementary remuneration (allowances). The fixed part of their remuneration is to give directors a sense of stability and security. The variable part, however, is intended link Board members' benefits with the effectiveness of their operational decisions, stimulating activities that integrate the business entity with companies operating in its environment. The economic performance with which the variable part of remuneration is to be linked should be understood broadly and take into account not only the efficiency aspects of the company's financial management, but also aspects of financial stability that are ever so important for the company's long-term viability and, consequently, for its shareholders.

\footnotetext{
* dr Agata Sierpińska-Sawicz, Uniwersytet Ekonomicznych w Poznaniu, Katedra Controllingu, Analizy Finansowej i Wyceny, e-mail: agata.sierpinska@ue.poznan.pl.
} 
The theoretical considerations and empirical studies presented in this paper review methods of determining bonuses for board members of State-owned companies. The study attempts to answer the questions "What metrics of objectives generally specified in relevant legislation have been embedded into management contracts and have these metrics been tailored to reflect the specificity of the industry in which a company operates and board members competencies?"

\section{Motivational character of bonuses}

Board members are duty bound to manage the affairs of a company and take active steps on its behalf. Efficient management of the company and the latter's attainment of reasonable financial results is rewarded with compensation. In order for it to have a certain incentivising force, compensation should be related to the company's performance. This motivational role of compensation is associated with bonuses. They are assumed to be a variable component of remuneration and depend on the fulfilment of the conditions that underlie their award. Variable effects are reflected by the variable size of bonuses. This variability exerts some pressure on a board member, as well as raises awareness that if he/she does not try hard enough, he/she will not get a bonus and that will mean lower remuneration. Additionally, the award or failure to secure the award of a bonus has a prestige dimension, which makes the bonus an important, flexible incentive tool (Borkowska, 2012, p. 374). According to Kawka, the bonus is a type of flexible pay, whose amount depends on a board members' attainment of targets in accordance with the adopted criteria (Kawka, 2002, p. 138). M. Kopertyńska emphasises that the design of a rational bonus system in specific circumstances requires identification of the tasks for which the bonus will be awarded, as well as of assessment criteria, i.e. the manner of measuring the degree of target or task achievement, the principles of linking achievement with the bonus level and conditions underlying a bonus award (Kopertyńska, 2000, p. 128). The variable part of remuneration is assumed to have primarily an incentivising function. Thanks to the bonus, supervisory boards obtain a tool allowing them to reward those board members who have made the largest contribution to building the company's market position and making an impact on employees' involvement (Meysztowicz, Policewicz et al., 2016, pp. 46-49).

According to Sedlak, the bonus is a key element of effective management of the remuneration system. It constitutes that portion of remuneration that should be strictly related to the company's performance. Moreover, variable pay is an ideal motivational tool due to its flexibility and ease of use. It is even pointed out that it should be the most important part of remuneration, as it alone permits a close alignment of pay, efficiency and performance. Variable remuneration is often referred to as "non-guaranteed pay" or risk pay. This emphasises the fact that all kinds of variable components will be the most important remuneration tool (Sedlak, 2014, p. 10). 
According to many economists, bonuses - the variable part of remuneration - should be related to the economic effects achieved by companies. The selection of proper metrics to assess a company's economic effects and the mechanism linking the latter to the level of directors' bonuses is of critical importance in the implementation of such incentive mechanisms. The mechanisms linking board members' bonuses with the economic effects of companies may have the following character (Sokołowski, Jóźwicki, 2010, p. 473):

- task-related,

- parametric,

- participatory.

In the first of the above, the mechanism used to determine the bonus consists in defining a single metric or a set of metrics with which company performance can be assessed and subsequently attribute to it fixed bonus amounts expressed either as an amount or a percentage of the basic pay. These amounts depend on the attainment level of a given metric, its being within a certain range or its increase relative to the previous period. The parametric method of linking the company performance with the amount of the bonus consists in determining a quantitative parameter linking the amount of bonuses obtained by managers with a specific metric of the obtained effects or indeed with several metrics. A typical example involves a parameter linking an increase in the bonus with a change in the bottom line relative to the previous year or a predetermined base figure. The third bonus mechanism specifies that a board member's bonus is a percentage share of the generated profit/loss. This is the so-called financial participation scheme giving the company's management a share in the company's profits, and these days the plan often benefits all employees. This model is therefore an element of an overall mechanism underlying the division of the company's profit.

A PwC's study reveals that the share of bonuses and incentives in the total remuneration of directors of WSE-listed companies rose from $25 \%$ in 2014 to $36 \%$ in 2015 slightly fell to the level of $30 \%$ in 2016 (Table 1).

\section{Table 1}

Pay structure of board members in companies listed on the WSE in 2014 and 2015

\begin{tabular}{llll}
\hline Description & 2014 & 2015 & 2016 \\
\hline Basic pay & 58 & 54 & 58 \\
Bonuses and incentives & 25 & 36 & 30 \\
Other constituents of pay & 8 & 4 & 4 \\
Remuneration from dependent entities & 9 & 6 & 8 \\
\hline
\end{tabular}

Source: author's own research based on a PwC Report "Analiza wynagrodzeń zarządów i rad nadzorczych 2016", p. 12.

Business press features an ever-larger number of opinions calling for top managers' remuneration to be capped. According to P. Masiukiewicz, the routes to this goal are many 
and varied. First of all, one can envisage the creation of an international deontological code of motivational rules for managers. Secondly, an enrichment tax of $80 \%$ across national borders or a maximum annual pay scheme could be enforced. The market economy should not be bound by too many constraints, therefore special tax regulations would appear to be the best solution (Masiukiewicz, 2010, p. 59).

\section{Bonuses of board members in State-owned companies}

Until 2016, the method of determining management remuneration was set out in the socalled Public Sector Salary Cap Act (ustawa kominowa). Board members in State-owned companies were entitled to receive a maximum of six times the average remuneration in the enterprise sector or four times that remuneration. Additionally, managers became eligible for additional benefits awarded on the basis of provisions other than the Salary Act (Ustawa o wynagrodzeniach osób kierujących..., 2000).

The Act of 9 June 2016 on the rules of determining the remuneration of managers in certain companies realigned the remuneration of board members in State-owned companies and entities owned by local self-government (Ustawa o zasadach kształtowania..., 2016). Pursuant to the new regulations, board members in State-owned companies must sign civil law contracts for the provision of management services for the duration of their term of office as company directors. The rationale behind the changeover is that a contract permits a stronger linkage of remuneration and performance. The terms and conditions of these contracts should be set out in board resolutions on the principles of board members' remuneration. A contract for the provision of management services may be terminated by the company, although it may provide for different periods of notice, depending on the actual duration of service, as long as such notice does not exceed three months, or it may provide that the notice period expires at the end of a calendar month. The new legislation introduced an important change. The new regulations ban pay (Article 5) for sitting on the supervisory body of subsidiaries within the capital group (within the meaning of Article 4, item 14 of the Competition and Consumers Protection Act of February 16, 2007). Board members are required to disclose their intent to perform functions in the bodies of another commercial company or to acquire shares therein.

Pursuant to the provisions of the Act, remuneration is constituted of a fixed part and a variable part conditional upon attainment by the managers of management-grade objectives. The objectives are laid out in art. 4.6 of the Act (Ustawa o zasadach kształtowania wynagrodzeń.., 2016):

- boosting net income or EBITDA or a favourable change in growth rate of one of these,

- reaching or changing output or sales volumes,

- boosting revenues, in particular sales revenue, operating revenue, other operating or financial revenue,

- reducing losses, SG\&A expenses or operating expenses, 
- implementing a strategy or a restructuring plan,

- reaching or changing certain targets, in particular profitability, liquidity, management efficiency or solvency targets,

- executing investment projects, with particular emphasis on their size, rate of return, innovativeness and timeliness of implementation,

- changing a company's market position in terms of market share or other criteria or relationships with contractors defined as key ones according to predefined criteria,

- implementing HR policy and boosting employee involvement.

For companies filing consolidated financial statements under the provisions of the accounting law, the adopted management objectives apply to the parent company and its subsidiaries at all levels as if the capital group constituted a single entity.

The above management objectives do not exhaust the list of parameters that may be taken into account in determining the variable part of remuneration. However, they constitute an open list containing proposals of sample management objectives. The General Meeting of Shareholders or Members may set other management objectives tailored to the specifics of the company's operations, its economic and financial situation, investment or restructuring programs implemented each time this is deemed appropriate.

The variable part of a board member's remuneration constituting a supplementary part of his/her remuneration during the company's financial year depends on the level of implementation of management objectives. The importance of management objectives, as well as objective and measurable criteria of their implementation and accounting are set for individual or all members of the management body. In the case of companies implementing a mission or fulfilling public tasks, definition of management objectives, their weightings and criteria of their implementation and accounting take into account the degree of fulfilment of these tasks and implementation of missions during the period constituting the basis for determining the supplementary pay. The variable part of remuneration in a company and in a public company must not exceed respectively 50 and $100 \%$ of the basic pay of board members during the previous financial year. The resolution setting out the remuneration of board members must stipulate that the variable part of their remuneration is paid after the directors' report on the company's activity and the company's financial statements for the previous financial year have been approved and the directors themselves have been granted a discharge in recognition of the performance of their duties by the General Meeting.

Management objectives should be commensurate with the type of activity pursued by the company, the current market situation and other economic factors affecting the degree of objectives achievement, e.g. change in the market price of raw materials. Management objectives should include both financial and non-financial objectives. Financial targets should be selected according to the type of activity pursued by the company. The selection process of management objectives and associated metrics should be individualised and preceded by a detailed analysis of the company's current situation, taking into account its strategy and public objectives. 


\section{Results of empirical research}

The research into the variable remuneration of management board members in companies with a state shareholding was carried out in two large capital groups. It covered a total of 25 companies, including two large parent companies in the raw materials sector and 23 subsidiaries. Due to the confidentiality of the payroll data, the names of companies are not disclosed. The object of the research was limited to an analysis of remuneration. The author focused on the metrics measuring the degree of attainment of objectives, their weight in the overall assessment and ways in which the bonuses are linked to the results achieved.

Table 2

Criteria of bonus awards to directors of business conglomerates 1

\begin{tabular}{|c|c|c|c|c|c|c|}
\hline Metric & $\begin{array}{l}\text { Parent } \\
\text { company }\end{array}$ & $\begin{array}{l}\text { Assessment } \\
\text { criterion }\end{array}$ & $\begin{array}{l}\text { Weight } \\
(\%)\end{array}$ & Subsidiaries & $\begin{array}{l}\text { Assessment } \\
\text { criterion }\end{array}$ & $\begin{array}{l}\text { Weight } \\
(\%)\end{array}$ \\
\hline EBITDA $_{\text {LIFO }}$ & $\mathrm{x}$ & $\begin{array}{l}\text { Increase on } \\
\text { previous year }\end{array}$ & 30 & & & \\
\hline Increase in net income & & & & $\mathrm{x}$ & $\begin{array}{l}\text { Increase on } \\
\text { previous year }\end{array}$ & 20 \\
\hline Increase in sales revenue & $\mathrm{x}$ & $\begin{array}{l}\text { Increase on } \\
\text { previous year }\end{array}$ & 15 & $\mathrm{x}$ & $\begin{array}{l}\text { Increase on } \\
\text { previous year }\end{array}$ & 20 \\
\hline Current ratio & & & & $\mathrm{x}$ & $\begin{array}{l}\text { Meeting the } \\
\text { target }\end{array}$ & 30 \\
\hline Quick ratio & $\mathrm{x}$ & $\begin{array}{l}\text { Meeting the } \\
\text { target }\end{array}$ & 15 & & & \\
\hline Return on Equity (ROE) & $\mathrm{x}$ & $\begin{array}{l}\text { Increase on } \\
\text { previous year }\end{array}$ & 10 & & & \\
\hline $\begin{array}{l}\text { Return on capital employed } \\
\text { (ROCE) }\end{array}$ & & & & $\mathrm{x}$ & $\begin{array}{l}\text { Increase on } \\
\text { previous year }\end{array}$ & 10 \\
\hline Ability to service debt & $\mathrm{x}$ & $\begin{array}{l}\text { Meeting } \\
\text { covenants }\end{array}$ & 30 & & & \\
\hline Debt ratio & & & & $\mathrm{x}$ & $\begin{array}{l}\text { Decrease on } \\
\text { previous year }\end{array}$ & 20 \\
\hline
\end{tabular}

EBITDA $_{\text {LIFO }}$ - operating income adjusted for changes in the prices of raw materials + depreciation

Current ratio - current assets/current liabilities.

Quick ratio - (accounts receivable + short-term investments)/current liabilities

$\mathrm{ROE}$ - net income/ average shareholder's equity

ROCE - net income/ (shareholder's equity + debt liabilities)

Ability to service debt - Net debt / EBITDA

Net debt - short-term debt + long-term debt - cash \& cash equivalents

Debt - short-term debt + long-term debt/liabilities + equity

Source: author's own research based on the study of business conglomerates 1 .

Giving preference in the assessment process to the degree of implementation of shortterm management objectives may prompt directors to focus their efforts on their own remuneration rather than on the company's long-term objectives. Short-term performance can be streamlined by managers through actions harmful to the company in the long run, including cutting spending on employee training, research and development, promotion and 
marketing. These are outlays which bring long term effects. In addition, managers may reduce repairs and maintenance expenditures or fail to set up adequate risk provisions, especially because the vast majority of provisions are not tax deductible and do not diminish the tax base. It should also be noted that bonuses are paid for past performance (Tables 2 and 3 ).

\section{Table 3}

Criteria of bonus awards to directors of business conglomerates 2

\begin{tabular}{|c|c|c|c|c|c|c|}
\hline Metric & $\begin{array}{l}\text { Parent } \\
\text { company }\end{array}$ & $\begin{array}{l}\text { Assessment } \\
\text { criterion }\end{array}$ & $\begin{array}{l}\text { Weight } \\
(\%)\end{array}$ & Subsidiaries & $\begin{array}{l}\text { Assessment } \\
\text { criterion }\end{array}$ & $\begin{array}{l}\text { Weight } \\
(\%)\end{array}$ \\
\hline EBITDA & $\mathrm{x}$ & $\begin{array}{l}\text { Increase on } \\
\text { previous year }\end{array}$ & 30 & & & \\
\hline Increase in net income & & & & $\mathrm{x}$ & $\begin{array}{l}\text { Increase on } \\
\text { previous year }\end{array}$ & 30 \\
\hline Reduced loss & & & & $\mathrm{x}$ & $\begin{array}{l}\text { Change relative } \\
\text { to previous year }\end{array}$ & 30 \\
\hline Reduced SG \& A & $\mathrm{x}$ & $\begin{array}{l}\text { Relative to } \\
\text { previous year }\end{array}$ & 10 & & & \\
\hline Increase in sales revenue & $\mathrm{x}$ & $\begin{array}{l}\text { Relative to } \\
\text { previous year }\end{array}$ & 15 & $\mathrm{x}$ & $\begin{array}{l}\text { Increase on } \\
\text { previous year }\end{array}$ & 20 \\
\hline Debt ratio & & & & $\mathrm{x}$ & $\begin{array}{l}\text { Decrease on } \\
\text { previous year }\end{array}$ & 20 \\
\hline Quick ratio & $\mathrm{x}$ & $\begin{array}{l}\text { Meeting the } \\
\text { target }\end{array}$ & 15 & & $\begin{array}{l}\text { Meeting the } \\
\text { target }\end{array}$ & 10 \\
\hline $\begin{array}{l}\text { Return on Equity } \\
\text { (ROE) }\end{array}$ & $\mathrm{x}$ & $\begin{array}{l}\text { Increase on } \\
\text { previous year }\end{array}$ & 10 & & $\begin{array}{l}\text { Increase on } \\
\text { previous year }\end{array}$ & 10 \\
\hline $\begin{array}{l}\text { Return on capital employed } \\
\text { (ROCE) }\end{array}$ & & & & $\mathrm{x}$ & $\begin{array}{l}\text { Increase on } \\
\text { previous year }\end{array}$ & 10 \\
\hline Ability to service debt & $\mathrm{x}$ & $\begin{array}{l}\text { Meeting } \\
\text { covenants }\end{array}$ & 20 & & & \\
\hline
\end{tabular}

Source: author's own research based on a study of business conglomerates 2 .

Short-term metrics could include e.g.: an increase in net income, share of overdue liabilities in short-term liabilities, timely completion of orders. Long-term metrics could include: the degree of investment plan implementation, the share of sales revenues from regular customers in overall sales revenues, EVA increment.

Directors' remuneration should motivate management board members to achieve the objectives envisaged in the company's strategy. The variable part of their remuneration should be related not only to the company's profit/loss, but also take into account other areas of its activity which are affected by the economic environment. These involve such metrics of economic activity as market share, customer complaints, improvement of sustainable development, especially in respect of social and environmental issues. These indicators should reflect industry specificity. Although they affect the company's overall performance, the strength of their impact on performance may vary. In addition, they reveal a manager's effectiveness in implementing the company's external objectives in a competitive market. 
The award of a bonus cannot be based on an assessment of short-term, e.g. quarterly and annual results; indeed it should also include long-term objectives. The indicators mainly relate to the level of investments and innovations that ensure a company's development and the appropriate rate of capital growth. In measuring the latter target, the assessment mainly relies on the MVA and EVA metrics. In practice, EVA is used more often because it is free from the fluctuations of share price in the capital market, which is affected by a number of macroeconomic factors independent of the company's management decisions. Moreover, it should be added that in the structure of remuneration there is a need to ensure the right ratio of the fixed and variable parts of remuneration paid in periods for which bonuses are awarded and that portion the bonus that is paid for performance over a longer period (e.g. for the board's entire term of office). Excessive postponement of a significant portion of the bonus will not induce managers to take risk and seek new ventures, so as not to diminish the chances of obtaining a deferred bonus.

\section{Conclusions}

An analysis of pertinent publications and the bonus systems of managers in companies directly or indirectly owned by the State confirms a few broader conclusions. The introduction of relatively high basic salaries and bonuses for long-term company performance would prove to be a good approach to directors' bonuses. Under this approach, directors would suffer financially for their wrong decisions. Yet, in order for bonuses to have a motivational value, they must not be too far removed in time from the effects arising from directors' decisions. Therefore, it would seem that a more reasonable solution would be to involve the introduction of a two-pronged bonus system in State-owned companies; one for short-term results and one for long-term results encompassing the board's term of office. Short-term bonuses would be a kind of advance. This solution addresses the concern that managers have numerous opportunities to influence short-term results by reducing expenditure on machinery and equipment maintenance, promotion and marketing, $R \& D$ and employee training. The effects of such expenditures manifest themselves only in the long run; hence limiting expenditure on them will improve the metrics being the basis for short-term bonuses but at the same time will have a negative impact on the company's results and position in the long term.

The amount of the bonus should be proportional to the basic pay. A $20-30 \%$ ratio to the pay seems fairly reasonable. With two-step bonuses, short-term bonuses could account for $10-15 \%$ of the base pay and long-term bonuses could reach up to $30 \%$ of that pay.

The success of the bonus system hangs upon the selection of a proper set of objectives which should be commensurate with competences, a well-matched system of metrics measuring the degree of attainment of objectives, properly determined weights for individual metrics and the specification of conditions to be met to qualify for a bonus, i.e. requirements 
that must be met in order for the manager to receive a bonus. Bonus conditions should be determined in such a way as to be subject to thorough control.

The number of objectives rewarded with a bonus must not be excessive to ensure that the objectives do not overlap or mutually exclude each other. The weight system behind individual metrics should ensure that individual bonus criteria are attractive and show the importance of a given criterion for total short-term objectives. The objectives must arise from the company's strategy and its market position. In addition, they should be in line with competencies as the manager then has a direct impact on the level of their implementation. Thus, a director responsible for finance is more responsible for the company's liquidity than the production manager responsible for ensuring the high quality of products and services. Therefore, it would be advisable to vary weights when assessing the level of task implementation.

The bonus system introduced in state-owned companies does not seem to be rational. In large public companies, maximum bonuses may be equivalent to $100 \%$ of the fixed part of managers' remuneration, while in other companies with State ownership the same may be equivalent to $50 \%$ of that pay. The volatility of management conditions resulting from the high volatility of the business environment disrupts the measurement of the short-term effects achieved by companies. It is hard to determine to what extent results depend on the effort of managers and to how they reflect favourable market conditions. Hence, in the assessment of the degree of implementation of management objectives, it is essential to use suitable databases for comparison. Use can be made of the results of the previous periods, adopted planned values or external benchmarks.

\section{References}

Borkowska, S. (2012). Skuteczne strategie wynagrodzeń - tworzenie i zastosowanie. Warszawa: Wolters Kluwer. Kawka, T. (2012). Wynagrodzenia pracowników. In: T. Listwan (ed.), Zarządzanie kadrami. Warszawa: C.H. Beck. Kopertyńska, M. (2000). Systematyka płac przedsiębiorstwa. Prace Naukowe Akademii Ekonomicznej we Wrocławiu, Seria: Monografie i Opracowania, 134 (846), 234.

Masiukiewicz, P. (2010). Systemy motywacji top-menedżerów jako akcelerator kryzysu. Ekonomika i Organizacja Przedsiębiorstw, 9, 53-61.

Meysztowicz, K., Policewicz, K., Autonowicz, M. (2016). Premie uznaniowe. Personel i Zarządzanie, 12, 46-49.

Szułdrzyński, K. (ed.) (2016). Analiza wynagrodzeń zarząów i rad nadzorczych 2016. Raport PwC. Retrieved from : https://www.pwc.pl/pl/pdf/analiza-wynagrodzen-zarzadow-i-rad-nadzorczych-2016.pdf (30.12.2017).

Sedlak, K. (2014). Total rewards - przyszłość systemów wynagradzania. Benefit, 3, 9-12.

Sokołowski, J., Jóźwicki, R. (2010). Wynagrodzenia naczelnej kadry kierowniczej a wyniki ekonomiczne przedsiębiorstwa. Prace Naukowe Uniwersytetu Ekonomicznego we Wrocławiu, 144, 467-479.

Ustawa z 3 marca 2000 r. o wynagrodzeniach osób kierujących niektórymi podmiotami prawnymi (Dz.U. 2015, poz. 2099), (uniform text O.J. 2015 item 2099).

Rozporządzenie Rady Ministrów z 21 stycznia 2003 r. w sprawie szczegółowego wykazu świadczeń dodatkowych, które mogą być przyznawane osobom kierującym niektórymi podmiotami prawnymi, oraz trybu ich przyznawania, O. J. 2003, 14, 139.

Ustawa z 9 czerwca 2016 r. o zasadach kształtowania wynagrodzeń osób kierujących niektórymi spółkami (Dz.U. poz. 1202), (O.J. 2016, item 1202). 


\section{PREMIOWANIE CZLONKÓW ZARZĄDU W SPÓŁKACH SKARBU PAŃSTWA}

Streszczenie: $\mathrm{Cel}$ - Artykuł prezentuje systemy premiowania członków zarządu spółek z udziałem Skarbu Państwa i ich zastosowanie w spółkach.

Metodologia badań - Badania przeprowadzone zostały w dwóch dużych grupach kapitałowych z udziałem Skarbu Państwa. Objęły one łącznie 25 spółek, w tym dwie duże spółki matki z branży surowcowej oraz 23 spółki zależne. Analizie poddane zostały uchwały Rad Nadzorczych spółek, dotyczące oceny stopnia realizacji celów i sposobie powiązania premii z osiągniętymi wynikami.

Wyniki - Badania pokazują, iż przyjęte do premiowania cele nie są w pełni dostosowane do rodzaju prowadzonej działalności i aktualnej sytuacji rynkowej spółek. W większości są to cele krótkoterminowe, a przyjęte dla poszczególnych mierników wagi, nie odzwierciedlają kompetencji poszczególnych członków zarządu. Oryginalność/wartość - Ze względu na krótki okres obowiązywania rozwiązań prawnych i poufność danych w literaturze brak jest badań dotyczących premiowania członków zarządu spółek Skarbu Państwa. Wyniki badań pozwolą na poprawę systemów premiowania członków zarządu i zwiększenie ich skuteczności w osiąganiu celów spółek zawartych w ich strategiach.

Słowa kluczowe: cele zarządcze, mierniki realizacji celów, premie

\section{Citation}

Sierpińska-Sawicz, A. (2018). Bonuses to Board Members of State-owned Companies. Finanse, Rynki Finansowe, Ubezpieczenia, 1 (91), 381-390. DOI: 10.18276/frfu.2018.91-31. 